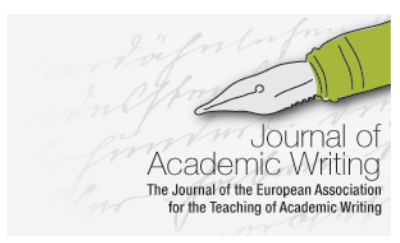

\title{
Digital Writing, Word Processors and Operations in Texts: How Student Writers Use Digital Resources in Academic Writing Processes
}

Sofia Hort

Södertörn University, Sweden

\begin{abstract}
This study explores the use of digital technologies in the writing of an academic assignment. Fine-grained studies on student writing processes are scarce in previous research. In relation to the increasing demands on students' writing, as well as the debate on students' poor writing (Malmström, 2017), these issues are important to address. In this study, screen captures of five students' essay processes are analyzed. The results show that students handle text at different levels: they make use of one or more word processors, arrange texts spatially on screens and use resources to operate directly in texts. Above all these actions seem to meet the need to move and navigate within one's own text, an aspect that could be especially important in relation to the academic genre and for handling texts as artifacts in activity (Castelló \& Iñesta, 2012; Prior, 2006). The results of the study point to the importance of making digital writing practices visible, especially those that could create possibilities to intertwine digital texts, thereby enhancing potentials for academic writing and meaning-making.
\end{abstract}

\section{Introduction}

There is a lack of fine-grained research on university students' digital writing processes (e.g. Aldridge \& Fontaine, 2016; Clayson, 2018; Gourlay \& Oliver, 2018; Prior, 2004; Rule, 2013, 2018). This is an issue that is important to attend to. One reason for this is that student writing is often being addressed as a problem (Lillis, 2001; Malmström, 2017; Stanley, 2010). The demands on students have, at the same time, amplified during recent decades, at least in the European context (Castelló \& Donahue, 2012, p. xv). Therefore, more knowledge is needed to improve writing instruction and, in a broader sense, to make the practices of academic writing accessible to all students.

This study relates to and opposes assumptions made of students as "digital natives" (Prensky, 2001). The latter view implies that students can manage digital technologies without teaching, at least not by higher educational institutions. Yet, the writing assignments in higher education do require a specific type of digital competence: they demand that students are able to find and read a huge amount of digital texts, shift between texts, relate texts to their own project, handle empirical data, analyze such data, and present this content in - by the standards of the specific academic community - an acceptable digital form. Academic writing thus demands awareness of how digital technologies can be used for specific academic writing purposes, an awareness that may not be evenly distributed in the student population.

With the aim to make visible what such awareness can mean, this study takes a detailed look at student digital writing and, more specifically, on the process of writing an essay. Previous research on writing processes emerged from a cognitive perspective, such as studies by Emig (1971) and Flower and Hayes (1981). The scope of writing process research has since then 
widened, broadening the concept of what writing means and, as a result, focusing more on how materiality, physical place, people and resources, not only the writer's cognition, affects writing processes (Hart-Davidson, 2007; Prior, 2004; Prior \& Shipka, 2003). Such widened concept of what writing means is especially articulated when taking a sociomaterial view, since this perspective strongly emphasizes that different materialities and resources not only represent tools for writing, but also act in the writing performed (Fenwick et al., 2015; Gourlay \& Oliver, 2018; Rule, 2013).

The materiality of writing is an issue that has been addressed in previous research. Often, researchers have been occupied by differences between constantly evolving digital technologies and the more traditional use of pen and paper. Mangen and colleagues (Mangen, 2016, 2018; Mangen \& Velay, 2010) studied how haptics, the movements of the hands, may have a positive impact on writing (see also Aldridge \& Fontaine, 2016; Dahlström \& Boström, 2017; Vlieghe, 2016). Digital writing is instead often judged to be superior when writing longer texts. Dahlström (2019, p. 1578) claimed that digital writing makes it easier for students to become designers of their own texts (see also Van Waes \& Schellens, 2003). At the same time, digital writing also creates challenges, specifically in relation to creating overviews of texts, what Haas labelled "text sense" (Haas, 1996, 1999). For today's students, digital writing is practically compulsory. Even though students still often do use handwriting as one mode of writing (Hort, 2020 ) it is not unreasonable to state that digital writing practices have become more and more dominant in all educational contexts. In relation to digital writing in particular, research also emphasizes that not only the materiality but also the design and interface of different software programs can affect in writing. Bray, for instance argues that the commonly used word processor Microsoft Word is clearly oriented towards the text product (rather than towards the writing process) (Bray, 2013, p. 203). In a comparison of Microsoft Word with other word publishers, Ching (2018) in the same sense describes Microsoft Word as "polished and professional" (p. 364).

This study attempts to draw examples of how university students use different software programs (mainly word processors) and how such programs, and the resources they entail, create opportunities and challenges when writing an essay text. Lea and Jones (2011) argued that existing research is lacking in in-depth and detailed examination of what students actually do in contexts when they are using different programs or digital applications, or how meanings are being made from, and through, engagement with these technologies (Lea \& Jones, 2011, p. 379). In Lea and Jones's study, the focus was on student writing of all sorts, including outside of the curriculum. They were thus emphasizing the plurality that is central to academic and digital literacies perspectives (Lankshear \& Knobel, 2015; Lea \& Street, 1998; Lillis, 2001), which also laid the groundwork for this study. Here, however, the focus is on one extensive writing assignment and hence on one academic, and digital, writing process in particular. To address the questions of how different software tools are used by students and how such programs and other digital resources can create opportunities and challenges when writing, the study draws on examples from fine-grained data of students' activities on screens as they write an academic essay. The focus is not on the materiality of the digital hardware itself, as in research presented earlier, but rather on the software that it entails, and how such software may influence the writing process (Bailey \& Withers, 2018; Bray, 2013; Ching, 2018)

\section{Research design}

Screen capture technology was used to generate data in this study. This technology has been increasingly adopted by researchers focusing on writing (Asselin \& Moayeri, 2010; Bailey \& Withers, 2018; Bhatt, 2014; Geisler \& Slattery, 2007; Kirkpatrick \& Klein, 2016; Seror, 2013; Takayoshi, 2015). Earlier studies have addressed the question of what screen captures can reveal about students' use of software tools for paraphrasing (e.g. Bailey \& Withers, 2018). Some studies have focused explicitly on revisions in the writing process (e.g. Elola \& Mikulski, 2013; Sabbaghan \& Maftoon, 2015), and some on how screen capture technology can be used as a pedagogical tool to give students feedback on their writing (e.g. Edwards et al., 2012; Silva, 2012). Overall, screen capture technology is being promoted by many researchers as a promising research and pedagogical tool. 
The study presented here is a small-scale study drawing on an overall project of student writing processes (Hort, 2020). A case study approach was adopted in order to gain understanding of this writing. The overall project includes data from a ten-week essay course from nine students (the students did however not take the course at the same time). This study specifically focuses on the screen captures of five of these students.

\section{Participants and universities}

Data was gathered on one or both of the participants' two final essays in the spring and autumn of 2016. Eight of the students in the overall project attended a Swedish teacher training program. One of the students attended a bachelor's program in social anthropology (see Table 1). A total of five students recorded screen captures during this data collecting phase. Four were teacher students and one were the student in anthropology. Two of the screen recording participants were male and three were female. Two of the students were followed during two essay courses, giving a total of seven essay processes being observed through screen captures.

The five participants succeeded in handing in their essays and received passing grades or better. The study is exploratory in its approach and the selection of participants makes no claims to being representative of the student population overall.

\section{The student essay}

The essay represents the most important project in the majority of the different teacher training programs in Sweden (The Swedish Higher Education Ordinance, 1993, p. 100). The essay as the term is used here also corresponds to an undergraduate paper or a degree paper. The essay course can be divided into smaller parts and vary in extent. However, the total amount of essay projects represents 30 ECTS and a second cycle degree exam (European Higher Education Area, 2005). In this study, most students wrote two essays for 15 credits each (half a semester) as part of their program and during their final year. The student in anthropology writes one essay for 15 credits at the end of the program. In these courses, students are supposed to independently carry out a study on a matter that is relevant to their subject. They are assigned a supervisor, whom they will meet with and discuss their text two or three times during this process. The essays are supposed to be approximately 20 to 60 pages long and are written in Swedish. The form of the essays is strictly regulated by a study guide. This document declares that the essays should be structured around the following section headings: Introduction, aim and research questions, previous research, theory, methods and materials, results and discussion. Notably, in most cases, the essays are supposed to be edited according to a specific essay template, which in the end means that students must edit the final version of the essay using the word processor Microsoft Word.

\section{Data gathering}

Students were informed of the study during their seminars at the university. They subsequently provided their email addresses if interested in participating in the study. Personal contact was then made with each student. The data collection followed the ethical principles stated by the Swedish Research Council (Vetenskapsrådet, 2011), and students gave their permission for using texts and screen shots in research publications. Participants names are in this publication replaced with pseudonyms for anonymity reasons.

The ten-week study was conducted by multiple means. The primary data for this study were the screen captures, created with a specialized software application that can record and save such recordings for future viewing of the audiovisual trail (Hamel et al., 2015). Five students recorded their screens at specific moments of their writing process. It was not possible, for practical as well as ethical reasons, to record screens every time students were writing. The moments of recording were instead chosen by students themselves and asked for at specific occasions by the researcher. This resulted in some variation in the amount of recorded material for each student, which is shown in Table 1 below. For instance, Karolin only recorded 1.6 hours of video material, which clearly represents a small sample in this case. The sample is included, 
however, as it entails a specific moment using overlapping screens that she specifically highlights as an important procedure in her process log and interview.

The screen captures were complemented by other types of data. Participants wrote process logs (Hart-Davidson, 2007; Prior, 2004; Roderick, 2019) using the so-called MTPL (mobile technologies and process logs) method (Hort, 2017) continuously during the writing process. Essay drafts and other texts were also collected during this time. After the essay was handed in, the students participated in one concluding interview. The main data in this specific study is based on the screen captures of the five students. However shared documents and interviews from the other four students participating in the overall project work as a complement in the analysis. Screen captures and shared digital documents are represented in Table 1.

\section{Table 1}

The five students participating in the small-scale study.

\begin{tabular}{lllll}
\hline Student & 2016 Term & Education & $\begin{array}{l}\text { Screen } \\
\text { captures } \\
\text { (hours) }\end{array}$ & $\begin{array}{l}\text { Digital } \\
\text { documents } \\
\text { (number) }\end{array}$ \\
\hline Eli & Spring & Teacher (lower grades) & 24 & 150 \\
Eli & Autumn & Teacher (lower grades) & 7.1 & 171 \\
Sally & Spring & 21 & 57 \\
Sally & Autumn & Teacher (high school) & 1.6 & 93 \\
Karolin & Spring & Social anthropology & 13 & 20 \\
Petra & Spring & (bachelor's) & 40 \\
Daniel & Autumn & Teacher (lower grades) & 3.5 & 49 \\
Sanna & Spring & Teacher student (lower & X & 129 \\
& & grades) & & 40 \\
Benji & Spring & Teacher student (lower & X & \\
& & grades) & & 29 \\
Ellen & Spring & Teacher student (lower & X & \\
& & grades) & & 22 \\
Ignazio & Spring & Teacher student (high & X & \\
& & school) & &
\end{tabular}

Note. Participating students marked in grey. The table also represents time of participation, educational program, amount of screen captures recorded (hours) and number of digital documents shared. Note that two students participated on two occasions. Students that participated in the overall project and whose texts and interview data worked as complement in the analysis are also included in this table (Sanna, Ellen, Benji, Ignazio).

\section{Data analysis}

The overall question that guided the analysis was how different texts are managed at various levels in the digital environment, in word processors as well as spatially on screens, and what text operations are central in these writings. A word processor is defined as a software program that enables input, editing, formatting and output of text. A mediating document is the term used for written documents that do not represent the essay draft (Kirkpatrick \& Klein, 2016). The use of different resources when directly acting in the text are categorized as text operations. In sum, the screen captures were viewed repeatedly to distinguish use of word processors, the writing 
of mediating documents and use of different text operations. The material was thus coded for different actions, such as change of software program, change of screen or text, or the use of text operations, such as changing font color or using the comment function. Some textual actions could also be visible in drafts and in these cases functioned as a complement in the analysis. The use of font color or the use of comments represent examples of actions that are visible in these texts.

The results of the coding of the screen captures were further compared to the shared digital drafts, as well as to the students' statements in the interviews and the process logs. The presentation of the analysis is complemented by screenshots of specific moments (decided by the researcher) in the screen captures or from specific parts of student's drafts. Text examples have been translated from Swedish to English by the researcher, directly in the texts if possible (drafts) or in the figure captions (screen captures).

\section{Results}

The results show that participating students sharing screen captures often handled their digital text in one document, their essay draft (four out of five of students). Hence, they did not use digital mediating documents to any great extent during the writing process. Some of these students, however, wrote analogue mediating documents, but as the focus here is on screen capture data and students' digital strategies, such writing was excluded from this analysis (for further elaboration on the analogue writing, see Hort, 2020). As the digital writing was mainly done in the essay draft, most students also exclusively wrote with the standard word processors, Microsoft Word or Google Docs. Some students used Google Docs as they did not have access to Microsoft Word on their own computers. This, however, meant that they needed to put their text into the essay template at the end of the course. Google Docs is very similar to Microsoft Word in its interface and design and could be said to represent a standardized word processor (Bray, 2013). The strategy of writing text directly in one essay draft is here labelled a one document strategy.

One of the students in the study, on the other hand, worked in a completely different manner, writing a huge amount of digital mediating documents in various word processors. This strategy is here labeled a distinctive writing strategy, as this student worked in distinctively different documents when writing texts with different purposes. The student, Eli, was unique in this context and his strategy should not be seen as representative of the student population. Yet, in the forthcoming presentation, this strategy is highlighted in comparison with the others, as it can give important insights into how digital resources can influence and shape writing, specifically in an academic writing context. The two different writing strategies distinguished, and how the use of word processors, the organization of screens and direct operations in text relate to these strategies are presented in Table 2. In the further sections these writing strategies will be elaborated in more detail. 
Table 2

Writing strategies in relation to word processors, organization of screen and direct operations in text

\begin{tabular}{ll} 
& $\begin{array}{l}\text { One document strategy } \\
\text { Working mainly in one } \\
\text { document }\end{array}$ \\
\hline Word processors & $\begin{array}{l}\text { Microsoft Word, Google } \\
\text { Docs }\end{array}$
\end{tabular}

Distinctive writing strategy Elaborating content in different documents

Microsoft Word, Google Docs,

Sticky Notes, Text Editor, transcribing programs (see note), Scrivener

\section{Organizing screen}

\section{Direct operations in text}

\author{
One window \\ Overlapping windows
}

\section{One window \\ Overlapping windows \\ Parallel windows}

Movement between parallel texts Using spatial layouts such as tables

\author{
Copying and pasting \\ Searching \\ Color \\ Comments \\ Dividing text in different \\ overlapping windows
}

Note. Other students in the study whom performed interviews have not been using transcribing programs. Instead they describe how they handle oral material by writing by hand or writing directly from recordings to Microsoft Word.

\title{
One document strategy
}

The students with a one document strategy mainly did their digital writing in the essay draft, and they wrote this document solely in a single word processor. One challenge that was raised by these students in relation to their digital writing was that they experienced the digital text as difficult to get an overview of and navigate within (Baron, 2009; Baron et al., 2017). This difficulty has been discussed by Haas in terms of lack of text sense in digital environments (Haas, 1996, 1999). For these students, the main essay draft also became comprehensive during the process, which may have inhibited the possibilities for moving and navigating between different parts of the text. The difficulties of navigation could be particularly important in an academic writing context, as writers may need to establish relations between different text sections, such as previous research and results.

Some of the text operations that were distinguished in in these essay drafts seem to address this challenge, as the use of semiotic resources such as color (highlighting or text color) or using demarcated text boxes (i.e. comments). These resources could help in making distinctions between different sections, words or paragraphs in the text. Text operations could also involve using the search function to navigate within the text or using the copy-paste function to move pieces of text within the document or between documents (thereby enabling the elaboration of texts in different sections, documents or windows). These operations are presented in more detail below.

Color is a common semiotic resource that was often visible in these students' screen recordings and drafts, and especially in Sally's, Sanna's and Ellen's writing. They all wrote a large amount of text during the process, and hence worked with a very comprehensive document. Color in these cases typically differentiated text that needed to be returned to and rewritten (or just erased). In the example in Figure 1, Sally is writing in the section labelled "previous research." In the black text section, she refers to one specific study, and then starts to write a text that she changes to a blue color. The blue text represents a reflection on the relevance of the previous research that she is paraphrasing in the previous sentences. She addresses herself (e.g. "Why is this important to me?") and also reflects upon the answer ("because..."). 
Sally, screen capture, October 29, 2016.

education s.5. Syftet bör vara att Förankra science, vidga deras perspektiv. Science innefattar både social och politic s.146. Varför är denna viktigt för mig? Därför att det är typ den enda bok som kommer upp när man söker på children och representation och sience. Därför att de har ett metodavsnitt och en metod som skiljer sig från min. Därför att den är övergripande.

Note: English translation (blue print): "Why is this important to me? Because this is the only book that comes up when searching on children and representation and sience [sic]. Because they have a method section and a method that is different from mine. Because it's comprehensive."

The same function - differentiating text - is visible in Ellen's heavy use of comments as well as color in her written texts (visible in her drafts). Figure 2 shows one such example. The green text in the body is a quote from another student essay. The green text is not supposed to be part of the final version of Ellen's essay ${ }^{1}$ and hence has another function (possibly inspiration). In the comment box to the right, Ellen discusses the analysis that is presented in this (other) essay and what the authors are doing in their analysis. She finishes the quote by stating: "COPY!", which represents a form of reminder to herself to do the same. In the comments, Ellen often seems to discuss and negotiate the norms of the genre, references to the literature, other students' essays (as seen in the example below), or the supervisor's statements.

\section{Figure 2}

Ellen, draft "results and analysis," March 14, 2016.

\begin{tabular}{|l|l|}
\hline " 4 Analysis of results & $\begin{array}{l}\text { See Ahlavist \& Karlsson beading."4 Analysis of } \\
\text { results" They present teaching materials analyzed in } \\
\text { the analysis of results because the results are presented } \\
\text { for every book. COPY! }\end{array}$ \\
$\begin{array}{l}\text { In this chapter the results are presented lof what we concluded with the aid of our instrument for } \\
\text { analysis. We begin with a short presentation of the different teaching materials with appurtenant } \\
\text { teacher guidance in two different chapters. WE have chosen to divide teaching material and } \\
\text { teacher guidance under two different subheadings. In the end of these two chapters a summary of } \\
\text { the results in relation to teaching materials and the teacher guidance follows" }\end{array}$ & \\
\hline
\end{tabular}

Note: The text in the figure is translated to English from Swedish by the author.

Overall, the content that frequently was marked out by colors or by using comments in Ellen's, Sanna's and Sally's texts needed revision and more reflection, and thereby worked as a form of guidance for further writing. These short texts seemed not directly to function as the final product but rather as artifacts in activity (Castelló \& Iñesta, 2012, p. 181; Prior, 2006, p. 58) or as a kind of mediating text in the essay draft (meditaing documents in Kirkpatrick \& Klein, 2016). Sally, Sanna and Ellen made distinctions between different functions of text sections in the essay draft by using semiotic markers (colors or boxes), probably in order to be able to navigate within their comprehensive essay documents.

When using a single word processor, the texts were handled mainly in one window. Sometimes the participants, however, needed to distinguish texts in different windows. The copy-paste function in these cases enabled students to move texts between documents. For instance, Karolin moved her results section by copying and pasting it into a new document. She then wrote her discussion in the essay document, but moved, by tabbing, between the copy pasted results located in a new window and the current essay text. This operation, in the same way as the font colors, distinguished texts from each other and thereby enhanced possibilities for navigation and movement between texts.

${ }^{1}$ Other students' essays are not valid previous research to reference in this context, according to norms and study guides. In this study it becomes visible how students instead use these texts as inspiration. 
In the interview, Karolin stated that she wanted the texts to lie next to each other to avoid scrolling. She also stated that she would have preferred to print the results section so that she could have the printed copy lying in front of her while writing. As this was not possible, she instead put it in another window on the screen, as shown in the screenshot in Figure 3.

\section{Figure 3}

Screen capture showing Karolin working with overlapping windows, May 4, 2016.

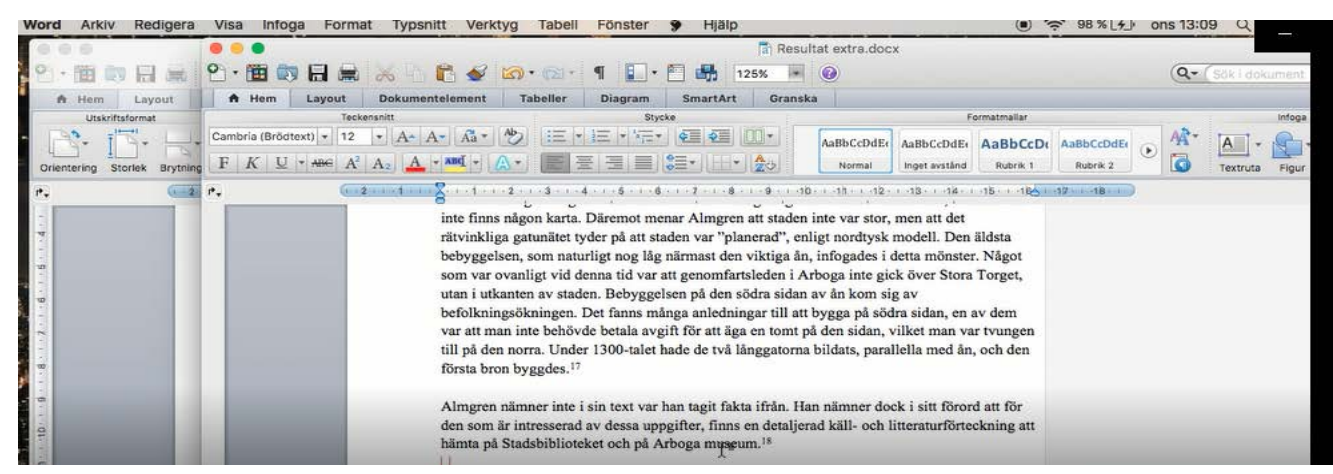

A similar action was described by Benji in his interview:

When I needed to rearrange my results ... I started in a new document instead. The only thing I did was that I looked at what I had written and then I rewrote it. The supervisor wanted me to rewrite it.... I copied and pasted, added things. (Benji, interview, spring 2016)

The copying and pasting are thus central when working with texts in different windows, which seems to be important when working close to, as in these cases, an earlier written part of the essay. A central argument for this is to avoid scrolling in one long text. For Karolin, it was about establishing proximity to the text that she needed to start out from when writing her discussion. For Benji, it seemed to be central to start on a new blank page when rewriting one part of the essay.

The analysis here does not claim that only students with a one document strategy make use of the operations presented. Data, however, points to the fact that such operations may be more extensively used in situations when handling long texts in a single word processor. Word processors in themselves enable different operations, as seen above. However, in the case of Microsoft Word, for instance, previous research has described it as being a "word publisher" rather than a program emphasizing the writing process (Bray, 2013; Ching, 2018). The results indicated here point to a potential non-reflected use of these word processors by students, which may complicate the academic writing process. The results above, however, also imply that these students made use of specific resources and operations in these programs to be able to handle, navigate and move within their essay text, hence enabling working out of a process orientation.

\section{Distinctive writing strategy}

According to the screen captures and the complementary data, Eli was the only student using word processors other than Microsoft Word or Google Docs. He was also the student who shared the most extensive amount of screen captures and text documents. What was characteristic of Eli's procedure was that he wrote a lot of texts during his process, but also that he used different word processors and worked with text in different and parallel windows. He highlighted, in the process logs and interviews, that different programs had distinct functions and therefore were good for various purposes. This aspect was central to Eli's writing strategy. He wrote his essay draft constantly in Microsoft Word, similarly to the rest of the students. He stated that Microsoft Word had some advantages, mainly that it was "robust," good for 
formatting, and hence for text design ("word publisher" in Bray, 2013). In Microsoft Word, Eli was therefore able to direct his writing at the product: the finished essay.

Central to Eli's procedure, however, was that he also used other word processors for writing other texts that did not become a product, what is here labelled as mediating documents. He wrote in Google Docs for more "mid-length things" or if the text he was writing was "more notelike, more comprehensive than shorter notes but not so gathered and finished" (Eli, process log, autumn). The Text Editor was another word processor he used, he claimed in the interview, because it was simple but still quite robust. He also argued that he used it as it gave him a good feeling and as "it was a nice interface; it most resembled an ordinary piece of white paper" (Eli, interview, autumn). Relating the digital technology to other analogue writing technologies in this way is also a theme that reoccurred in Ching's study. Ching claimed that it is important for writers that the spatial framing is perceived as "analogue or non-digital" (2018, pp. 363-365). In Eli's case, the analogue feeling seemed to imply that the writing was not product-oriented, thus having another function than texts that are written in Microsoft Word. Similar reflection is visible in Sanna's process log, where she discussed her preference for analogue writing.

In the excerpts shown in the Figures 4-7, Eli was writing an essay in which he was analyzing conversations with pupils over interactive map applications. He transcribed those conversations in a specific transcribing program and then saved the transcriptions in the Text Editor. These transcriptions were central to his analysis and further writing. At the time of this screen capture, he had finished the data collection phase and had approximately two weeks until the essay was to be handed in. In the screenshot below he was working closely with the transcriptions. Four different documents (two in Text Editor and two Sticky Notes) are visible on the screen at the same time. In Figure 4, Eli was writing in the middle window. The short notes in these documents, often arranged in a list-like order, are words or statements from the empirical data that Eli was categorizing and experimenting with under different headings.

\section{Figure 4}

Eli, screen capture, November 15, 2016.

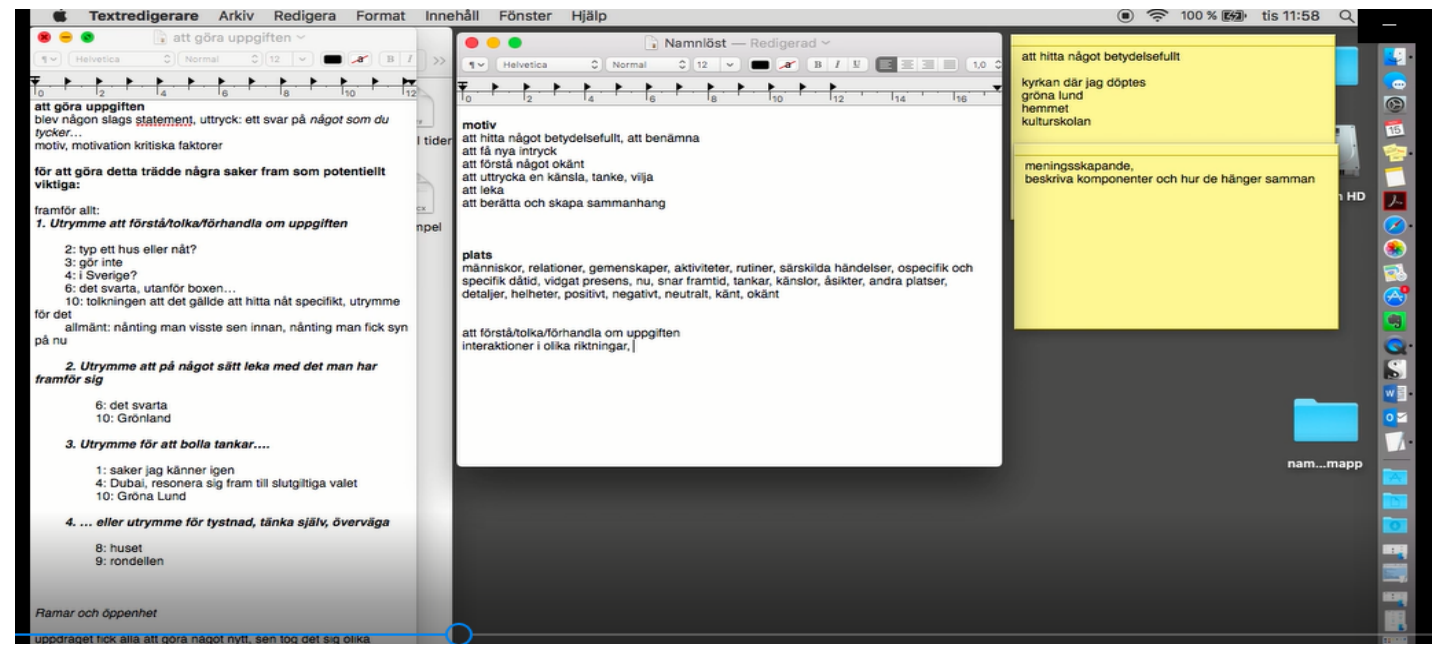

In Figure 5, Eli opened the main document (the essay text) and scrolled down to the transcripts of videos and conversations located in the main document (to the left). He then wrote in the document to the right (unnamed document, Text Editor): "Interactions in different directions" and "what you have in front of you," which could be described as analytical notations on the empirical data written in the main document. 


\section{Figure 5}

Eli, screen capture, November 15, 2016

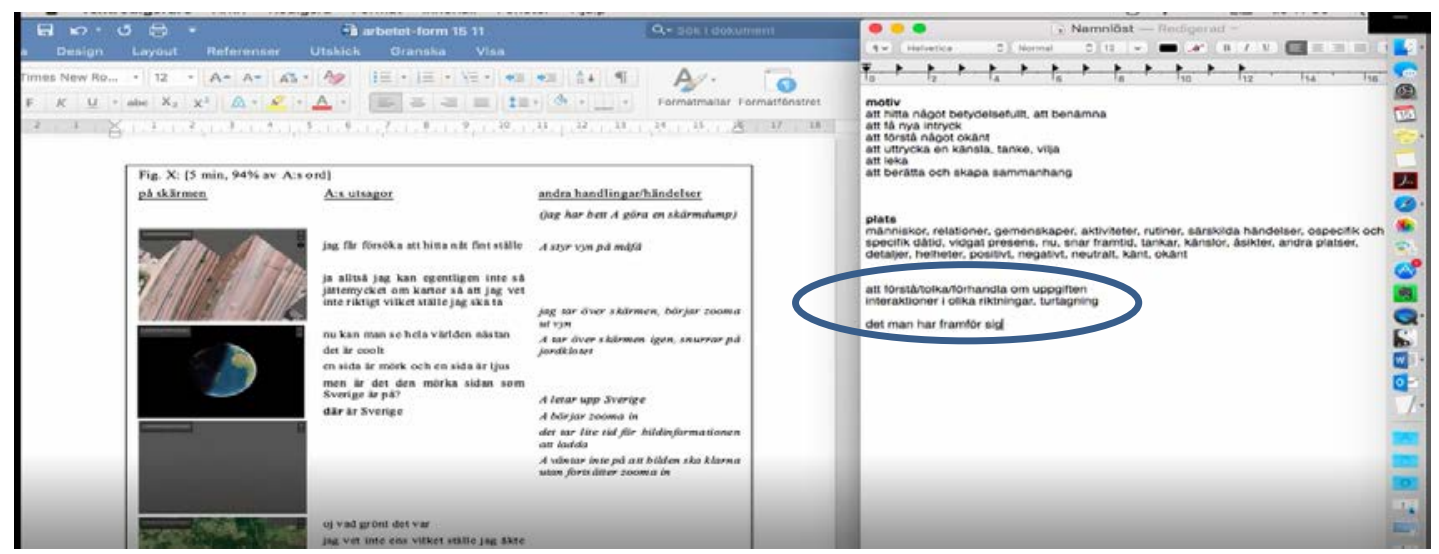

Note: Marked text states: "to interpret/negotiate about the assignment. Interactions in different directions interactions in different directions, turn taking. What one has in front of oneself."

He then moved the window of the Text Editor to make the Sticky Notes visible again, which is shown in the screenshot in Figure 6. In these notes, he wrote "design" and "rhizome." He made one heading - "design" - bold and started to write down quotes from a book (sounds from the film indicate that he was now browsing through a physical book).

\section{Figure 6}

Eli screen capture, November 15, 2016.

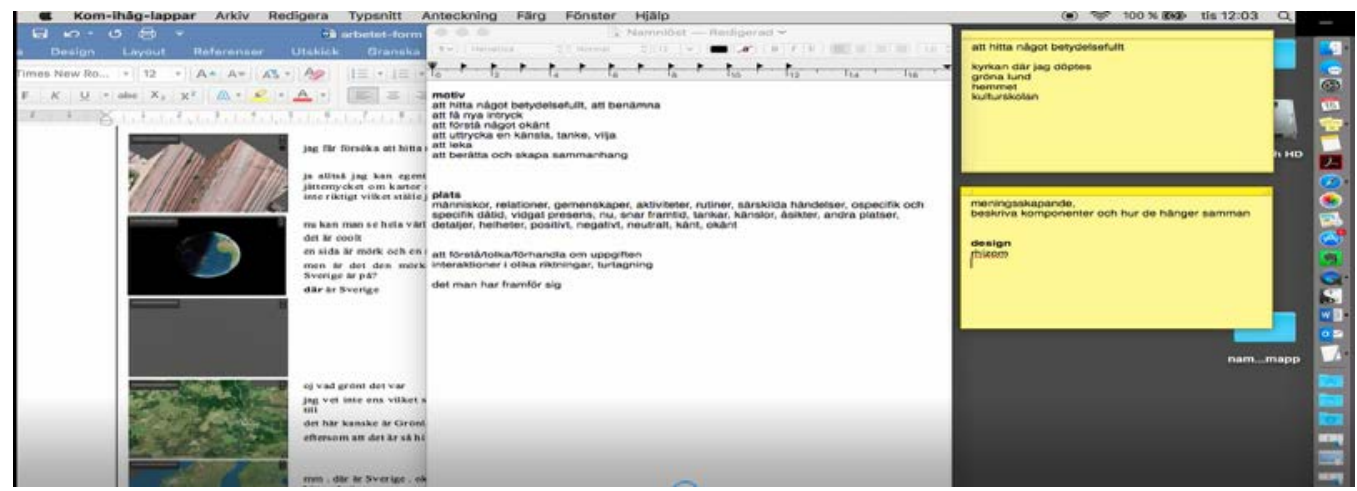

In Figure 7, he continued to write: "orient oneself and create meaning in a situation, out of one's own interests (104)" and "a constantly ongoing process in a number of micro-situations (105)" (marked out in Figure 7). Instead of working more directly with the empirical data as in the examples above, Eli turned to processing the literature, though in relation to the themes in the analysis. 


\section{Figure 7}

Eli, screen capture, November 15, 2016

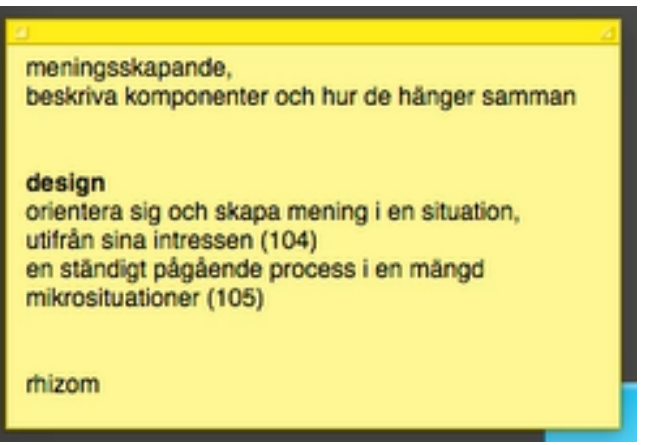

Note: The note at the top reads: "meaning-making, describe components and how they connect." The second part, under the heading "design," reads: "orient oneself and create meaning in a situation, out of one's own interests (104)," then "a constantly ongoing process in a number of micro situations (105)," and, finally, "rhizome."

Eli's writing here clearly intertwined processes of analysis with processes of working with the literature by using a specific spatial layout of the screen together with various word processors. This new knowledge, the result of the analysis of his transcripts, seems to be stabilized in what could be described as rather humble objects, in this case, a Sticky Note ("humble objects" in Fenwick \& Edwards, 2010, p. 28). Eli's procedure shows the importance of finding proximity between texts to be able to move quickly and create relations between them. This is the same argument for using different resources in a one document strategy. The excerpts from Eli, however, more clearly illustrate how an intertwined and parallel process of working the literature, performing the analysis and writing the product could be performed. Different processes were demarcated in different documents but were at the same time intertwined in the parallelism that was often central in Eli's writing processes. The differentiation of text in parallel documents and in various word processors that becomes apparent in Eli's writing process may make it less important to distinguish specific parts of the texts by different operations in the document, such as using color and comments. Traces of such operations were equally absent in Eli's screen captures and in the documents he shared during the process.

In sum, there are several examples of how Eli used different word processors (and reading programs) in parallel windows in order to process the literature and perform the analysis. In this work, he made the process of analysis explicit - for himself, but also for me as a researcher. This process of analysis was instead more implicit in the other students' shared data. That is, they did not use mediating documents or writing to perform these operations. An analysis was clearly performed as they finished with their essays; however they did not write their different operations or steps in this process down (as Eli did). Overall, the students also reported on difficulties in understanding what an analysis really meant.

\section{Conclusions}

The results of this study indicate that the participating students mainly used a single word processor when writing their essays. This is in line with what previous research has claimed: that students seem more unfamiliar with other word processing tools than they do with the most standardized, such as Microsoft Word or Google Docs (Bailey \& Withers, 2018; Bray, 2013; Ching, 2018). However, although it has been described as "polished and professional" (Ching, 2018), Microsoft Word also has resources that enable writers to work more with texts in a process. The students in this study used resources such as color and comments to be able to handle texts as "artifacts in activity" (Castelló \& Iñesta, 2012, p. 181; Kirkpatrick \& Klein, 2016; Prior, 2006, p. 58). 
Results showed however also how one student used several other word processors. In this sense, he differentiated word processors, texts and their functions, thereby handling texts in various and extensive ways. In his writing process, texts were treated more explicitly, in clearly distinct mediating documents, as "artifacts in activity" (Prior, 2006, p. 58). The procedure of working with texts and distinguishing different text work in different programs seemed to be very successful for him.

These illustrations point to the importance of highlighting for student writers how writing can work in different ways, not just for writing the product (Prior, 2006). In relation to the different functions of writing, it also becomes important to show how writing technologies (in this case digital) can work and influence writing in different ways. In academic writing, it is important to navigate and move between digital texts. The procedure Eli demonstrated enabled him, in that sense, to improve his text mobility by creating proximity between the texts with which he worked with by using different digital resources. Other students instead often spoke of their texts during the process as being overwhelming and messy.

The study shows some fine-grained examples of how digital technology can provide different opportunities to make meaning through writing, or in other words how writers can mobilize different digital resources when "writing to learn" (e.g. McCutchen, 2008). It is however not certain that the possibilities of the writing technology in itself are apparent for all students. I argue that it is a certain digital awareness that is important for academic writing. Students need to be able to intertwine texts and technologies to be able to work with the meaning-making that is fundamental to academic writing (Lea \& Jones, 2011, p. 385).

Universities instead often seem to take digital abilities for granted. This is in line with an overall view of students as "digital natives" (Thomas 2011). Digital abilities, however, may be shallow and not specifically directed toward academic writing. Bailey and Whiters' results seem to imply that it is possible for students to write well without software aids (Bailey \& Withers, 2018, p. 185). It is possible that this is the case, but the essay represents a very comprehensive and difficult assignment. The ten-week essay process entails many challenges, such as the administration of a comprehensive text and research process for a long time. In the present study, I have illustrated how digital resources are used by some student writers. Considering these illustrative examples, it is, for instance, valuable to reflect on how meanings are being made through the process of writing in different ways and how such issues could be successfully taught upon.

The study suggests that academic literacy entails dimensions that have not been given enough attention in research. Digital procedures, as working with parallel texts or windows and the use of different word processors in relation to academic writing, are actions that also could be made more visible in research on academic writing. Students should be well-informed of how resources can be used, as to be able to apply what they need in their own writing process. Further research could for instance compare groups that have and have not received such training.

This is a small-scale qualitative study of a few cases, and it makes no claims to being generalizable. However, it is drawing fine grained examples from a larger material to indicate its potential to add to our understanding of academic digital writing. Issues of operability, transferability and validity, however, need to be highlighted in further studies of writing process. Furthermore, studies of digital writing also need to be complemented by other data, as writing is not just digital, but distributed between the embodied, material and physical. 


\section{References}

Aldridge, M., \& Fontaine, L. (2016). The impact of mode on writing processes: A cognitive functional perspective on student writing. Special Issue on SFL and Development in Writing and Reading Competence in Language Education, Revista de Lenguas y Culturas Extranjeras, 7, 7-32.

Asselin, M., \& Moayeri, M. (2010). New tools for new literacies research: An exploration of usability testing software. International Journal of Research \& Method in Education, 33(1), 41-53. https://doi.org/10.1080/17437271003597923

Bailey, C., \& Withers, J. (2018). What can screen capture reveal about students' use of software tools when undertaking a paraphrasing task? Journal of Academic Writing, 8(2), 176190. https://doi.org/10.18552/joaw.v8i2.456

Baron, D. (2009). A better pencil: Readers, writers, and the digital revolution. Oxford University Press.

Baron, N. S., Calixte, R. M., \& Havewala, M. (2017). The persistence of print among university students: An exploratory study. Telematics and Informatics, 34(5), 590-604. https://doi.org/10.1016/i.tele.2016.11.008

Bhatt, I. (2014). A sociomaterial account of assignment writing in Further Education classrooms [PhD thesis, University of Leeds]. Leeds, United Kingdom.

Bray, N. (2013). Writing with scrivener: A hopeful tale of disappearing tools, flatulence, and word processing redemption. Computers and Composition, 30(3), 197-210. https://doi.org/10.1016/j.compcom.2013.07.002

Castelló, M., \& Donahue, C. (2012). University writing: Selves and texts in academic societies. Emerald.

Castelló, M., \& Iñesta, A. (2012). Texts as artifacts-in-activity: Developing authorial identity and academic voice in writing academic research papers. In M. Castelló \& C. Donahue (Eds.), University Writing Selves and Texts in Academic Societies (pp. 179-201). Emerald.

Ching, K. L. (2018). Tools matter: mediated writing activity in alternative digital environments. Written Communication, 35(3), 344-375. https://doi.org/10.1177/0741088318773741

Clayson, A. (2018). Distributed writing as a lens for examining writing as embodied practice. Technical Communication Quarterly, 27(3), 217-226. https://doi.org/10.1080/10572252.2018.1479607

Dahlström, D., \& Boström, B. (2017). Pros and cons: Handwriting versus digital writing. Nordic Journal of Digital Literacy, 12(04), 143-161. http://urn.kb.se/resolve?urn=urn:nbn:se:miun:diva-32485

Dahlström, H. (2019). Digital writing tools from the student perspective. Education and Information Technologies, 24(2), 1563-1581. https://doi.org/10.1007/s10639-018-9844-x

Edwards, K., Dujardin, A.-F., \& Williams, N. (2012). Screencast feedback for essays on a distance learning MA in professional communication: An action research project. Journal of Academic Writing, 2(1), 95-126. https://doi.org/10.18552/joaw.v2i1.62

Elola, I., \& Mikulski, A. (2013). Revisions in real time: Spanish heritage language learners' writing processes in English and Spanish. Foreign Language Annals, 46(4), 646-660. https://doi.org/10.1111/flan.12053 
Emig, J. (1971). The composing processes of twelfth graders (N. C. o. T. o. English, Ed. Vol. 13). National Council of Teachers of English.

European Higher Education Area. (2005, 19-20 May). The European Higher Education Area: Achieving the goals. Conference of European Ministers Responsible for Higher Education, Bergen.

Fenwick, T., \& Edwards, R. (2010). Actor-network theory in education. Routledge.

Fenwick, T., Edwards, R., \& Sawchuk, P. (2015). Emerging approaches to educational research: Tracing the socio-material. Routledge.

Flower, L., \& Hayes, J. R. (1981). A cognitive process theory of writing. College Composition and Communication, 32(4), 365-387.

Geisler, C., \& Slattery, S. (2007). Capturing the activity of digital writing: Using, analyzing, and supplementing video screen capture. In H. A. McKee \& D. DeVoss (Eds.), Digital writing research: Technologies, methodologies, and ethical issues (pp. 185-200). Hampton Press.

Gourlay, L., \& Oliver, M. (2018). Student engagement in the digital university: Sociomaterial Assemblages. Routledge.

Haas, C. (1996). Writing technology: Studies on the materiality of literacy. Routledge.

Haas, C. (1999). On the relationship between old and new technologies. Computers and Composition, 16(2), 209-228.

Hamel, M.-J., Séror, J., \& Dion, C. (2015). Writers in action: Modelling and scaffolding secondlanguage learners' writing process. Higher Education Quality Council of Ontario Toronto, Canada.

Hart-Davidson, W. (2007). Studying the mediated action of composing with time-use diaries. In H. A. McKee \& D. DeVoss (Eds.), Digital writing research: Technologies, methodologies, and ethical issues (pp. 153-170). Hampton Press.

Hort, S. (2017). Exploring the use of mobile technologies and process logs in writing research. International Journal of Qualitative Methods, 16(1). https://doi.org/10.1177/1609406917734060

Hort, S. (2020). Skrivprocesser på högskolan. Text, plats och materialitet i uppsatsskrivandet [PhD-thesis, Örebro University]. Örebro.

Kirkpatrick, L. C., \& Klein, P. D. (2016). High-achieving high school students' strategies for writing from internet-based sources of information. Journal of Writing Research, 8(1).

Lankshear, C., \& Knobel, M. (2015). Digital literacy and digital literacies: Policy, pedagogy and research considerations for education. Nordic Journal of Digital Literacy, 8-20.

Lea, M., \& Jones, S. (2011). Digital literacies in higher education: Exploring textual and technological practice. Studies in Higher Education, 36(4), 377-393. https://doi.org/10.1080/03075071003664021

Lea, M., \& Street, B. (1998). Student writing in higher education: An academic literacies approach. Studies in Higher Education, 23(2), 157--72. https://doi.org/10.1080/03075079812331380364

Lillis, T. M. (2001). Student writing: Access, regulation, desire. Routledge. 
Malmström, M. (2017). Synen på skrivande: Föreställningar om skrivande i mediedebatter och gymnasieskolans läroplaner [PhD-thesis, Lund University]. Lund.

Mangen, A. (2016). What hands may tell us about reading and writing. Educational Theory, 66(4), 457-477. https://doi.org/10.1111/edth.12183

Mangen, A. (2018). Modes of writing in a digital age: The good, the bad and the unknown. First Monday, 23(10). https://journals.uic.edu/ojs/index.php/fm/article/view/9419/7593

Mangen, A., \& Velay, J.-L. (2010). Digitizing literacy: Reflections on the haptics of writing. In M. H. Zadeh (Ed.), Advances in haptics (pp. 385-401). IntechOpen.

Prensky, M. (2001). Digital natives, digital immigrants part 1. On the horizon, 9(5), 1-6.

Prior, P. (2004). Tracing process: How texts come into being. In P. Prior \& C. Bazerman (Eds.), What writing does and how it does it (pp. 173-206). Taylor and Francis.

Prior, P. (2006). A sociocultural theory of writing. In C. MacArthur \& S. Graham (Eds.), Handbook of writing research (pp. 54-66). Guilford Press.

Prior, P., \& Shipka, J. (2003). Chronotopic lamination: Tracing the contours of literate activity. In C. Bazerman \& D. Russel (Eds.), Writing selves, writing societies: Research from activity perspectives (pp. 180-238). The WAC Clearinghouse and Mind, Culture, and Activity. https://innovationtest2.colostate.edu/books/perspectives/selves societies/

Roderick, R. (2019). Self-regulation and rhetorical problem solving: How graduate students adapt to an unfamiliar writing project. Written Communication, 36(3), 410-436. https://doi.org/10.1177/0741088319843511

Rule, H. (2013). Composing assemblages: Toward a theory of material embodied process [PhD-thesis, University of Cincinnati]. Cincinatti.

Rule, H. (2018). Writing's rooms. College Composition and Communication, 69(3), 402-432.

Sabbaghan, S., \& Maftoon, P. (2015). The affordances of screen capture technology for retrospective analysis of the writing process. International Journal of Research Studies in Educational Technology, 4(1).

Seror, J. (2013). Screen capture technology: A digital window into students' writing processes/Technologie de capture d'écran: une fenêtre numérique sur le processus d'écriture des étudiants. Canadian Journal of Learning and Technology/La revue canadienne de l'apprentissage et de la technologie, 39(3).

Silva, M. L. (2012). Camtasia in the classroom: Student attitudes and preferences for video commentary or Microsoft Word comments during the revision process. Computers and Composition, 29(1), 1-22. https://doi.org/10.1016/i.compcom.2011.12.001

Stanley, J. (2010). The rhetoric of remediation: Negotiating entitlement and access to higher education. University of Pittsburgh Press.

Takayoshi, P. (2015). Short-form writing: Studying process in the context of contemporary composing technologies. Computers and Composition, 37, 1-13. https://doi.org/10.1016/i.compcom.2015.04.006

Van Waes, L., \& Schellens, P. J. (2003). Writing profiles: The effect of the writing mode on pausing and revision patterns of experienced writers. Journal of pragmatics, 35(6), 829-853. https://doi.org/10.1016/S0378-2166(02)00121-2 
Vetenskapsrådet. (2011). God forskningssed (1:2011).

https://www.vr.se/download/18.2412c5311624176023d25b05/1555332112063/Godforskningssed VR 2017.pdf

Vlieghe, J. (2016). Schooling bodies to read and write: A technosomatic perspective. Educational Theory, 66(4), 441-455. https://doi.org/10.1111/edth.12182 